\title{
Identification of odorant-binding proteins in the reproductive system of Athetis dissimilis using transcriptome analysis
}

\section{Yueqin Song}

Henan University of Science and Technology

Huizhong Sun ( $\square$ huizhong66@163.com )

Henan University of Science and Technology https://orcid.org/0000-0002-3560-7625

Jingyun Zhao

Zhumadian Academy of Agricultural Sciences

\section{Research article}

Keywords: Athetis dissimilis, reproductive organs, transcriptome, odorant-binding proteins, expression profiles

Posted Date: December 20th, 2019

DOI: https://doi.org/10.21203/rs.2.19442/v1

License: () (i) This work is licensed under a Creative Commons Attribution 4.0 International License. Read Full License 


\section{Abstract}

Odorant-binding proteins (OBPs) are prevalent in the antennal transcriptomes of different orders of insects. Studies on OBPs have focused on their role in the insect chemosensory system, but knowledge of their functions in the insect testis is limited. We sequenced the transcriptomes of the Athetis dissimilis reproductive organs and analyzed the expressive of OBPs in different tissues. We identified a total of 54 OBPs including 23 OBPs in the transcriptomes of testis and ovaries, and 31 OBPs in antennal transcriptomes. Through fluorescence qPCR, the 23 identified OBPs were found to be highly expressed in both female and male antennae compared to the reproductive organs. Of the identified OBPs, $5 / 23$ showed comparable expression in female and male antennae; $3 / 23$ were more highly expressed in males compared to females; and 15/23 OBPs were more highly expressed in females compared to males. A total of 24 OBPs were highly expressed in the testis of $A$. dissimilis whilst expression in the ovaries was low. These findings highlight the functional diversity of OBPs in insects and can facilitate further studies on the OBPs in $A$. dissimilis and lepidopteran species.

\section{Background}

The olfactory system in insects regulates their intersex communication, host-plant interactions, oviposition, foraging, escape from predators and reproduction [1-5]. Insects have a complex chemosensory system in which pheromones and plant odors are initially recognized by odorant-binding proteins (OBPs) expressed in the antennal sensilla lymph that transfer the odorants to membrane-bound olfactory receptors (ORs) to activate olfactory receptor neurons (ORNs) and stimulate behavioral responses [6-11].

OBPs are small water soluble proteins that have six positionally conserved cysteines to form three interlocking disulphide bridges that stabilize the protein's three-dimensional structure [12-17]. OBPs were first discovered in the antenna of Antheraea polyphemus that distinguish [12] and bind to lipophilic odorant compounds [18-23]. However, emerging data suggests that OBPs are not restricted to the sensory organs of insect and show expression in non-sensory organs including reproductive organs. Li et al. showed that OBPs22 was highly expressed in the male reproductive organs of Aedes aegypti and transfers to females during mating as a carrier for the urine and saliva of vertebrate [24]. Sun et al. also found that OBP10 is highly abundant in seminal fluid of Helicoverpa armigera and $\mathrm{H}$. assulta and transfers to female during mating. OBP10 also binds 1-dodecene, a known insect repellent [25].

Athetis dissimilis Hampson (Lepidoptera: Noctuidae) is an important agricultural pest. Li et al. distinguished A. dissimilis from A. lepigone [26] that mainly distributes to Asian countries including China, Japan, Philippines, Korea, Indonesia and India causing serious damages to maize, wheat, peanut, soybean and sweet potato [27-28]. Because of the fact that larvae of A. dissimilis live under plant residues, it is difficult to control the spread of the pest with chemical pesticides. Therefore, novel control managements are urgently needed to mitigate crop damage. We first sequenced the antennal transcriptomes of $A$. dissimilis [29] and characterized 5 OBPs that showed tissue-specific expression patterns [30].Of note, AdisOBP6 was highly expressed in the testes of A. dissimilis [30].We reasoned that the testis of insects possess a defined set of OBPs in a manner comparable to the antenna. In this study, we sequenced the transcriptomes of the A. dissimilis reproductive organs and studied the expression of the OBPs in the antenna of female and males and testis and ovaries, and provide new targets for pest management in the future.

\section{Results}

\section{Illumina sequencing and assembly}

A total of $34,565,866,32,154,799$, and $26,952,526$ clean reads containing $10.35,9.63$, and 8.07 giga base (Gb) pairs of clean nucleotides respectively, were obtained from the three replicates of the A. dissimilis ovaries. A total of $27,752,168,28,900,040$, and $30,838,686$ clean reads containing $8.29,8.65$ and 9.23 giga base $(\mathrm{Gb})$ pairs of clean nucleotides respectively, were obtained from the three replicates of $\mathrm{A}$. dissimilis testes. The quality of the transcriptome sequences was high, with Q30 percentages of $94.03 \%, 94.36 \%, 94.21 \%, 94.42 \%, 94.27 \%$ and $94.01 \%$ for the three replicates of A. dissimilis ovaries and testes, with a GC content were 50\% (Table 1). Then 221,074 transcripts and 82,016 unigenes with N50 length of 1,350 and 1,243, were obtained from assembled using Trinity (Table 2).

Table 1

Summary of the sequence assemblies according to the RNA-seq data of the A.

dissimilis.

\begin{tabular}{|llllll|}
\hline \multicolumn{2}{|c}{ Sample name } & Clean reads & Clean bases & GC Content (\%) & Q30 (\%) \\
\hline \multirow{2}{*}{ Ovaries } & Repeat 1 & $34,565,866$ & $10.35 \mathrm{G}$ & 48.00 & 94.03 \\
\cline { 2 - 6 } & Repeat 2 & $32,154,799$ & $9.63 \mathrm{G}$ & 48.35 & 94.36 \\
\cline { 2 - 6 } & Repeat 3 & $26,952,526$ & $8.07 \mathrm{G}$ & 48.27 & 94.21 \\
\hline \multirow{2}{*}{ Testis } & Repeat 1 & $27,752,168$ & $8.29 \mathrm{G}$ & 48.85 & 94.42 \\
\cline { 2 - 6 } & Repeat 2 & $28,900,040$ & $8.65 \mathrm{G}$ & 47.20 & 94.27 \\
\hline
\end{tabular}


Table 2

Summary of de novo assembly of the A. dissimilis transcriptomes.

\section{Functional annotation}

\begin{tabular}{|lllll|}
\hline Length Range & Transcript & Rate\% & Unigene & Rate\% \\
\hline$<300$ & 0 & 0 & 0 & 0 \\
$300-500$ & 83,670 & 37.85 & 37104 & 45.24 \\
\hline $500-1000$ & 70,088 & 31.70 & 24792 & 30.23 \\
\hline $1000-2000$ & 44,935 & 20.33 & 12864 & 15.68 \\
\hline$>2000$ & 22,381 & 10.12 & 7256 & 8.85 \\
\hline Total Number & 221,074 & & 82,016 & \\
\hline Total Length & $216,261,287$ & & $73,549,396$ & \\
\hline N50 Length & 1,350 & & 1,243 & \\
\hline Mean Length & 978.23 & & 896.77 & \\
\hline
\end{tabular}

Significant matches of 33,587 unigenes (96.91\%) in the NR; 29,936 (86.38\%) in the eggnog; 20,134 (58.09\%) in the Pfam; 15,174 (43.78\%) in the Swissprot database; 14,775 (42.63\%) in the KEGG; 7,797 (22.50\%) in the GO; and 6,712 (19.37\%) in the COG were observed. As a result, up to 34,658 putative coding sequences were identified (Table 3). NR database queries revealed a high percentage of A. dissimilis sequences that closely matched to sequences of Helicoverpa armigera (19072, 56.87\%), Amyelois transitella (1936, 5.77\%), Bombyx mori (1543, 4.60\%), Papilio machaon (1155, 3.44\%), Papilio xuthus (868, $2.59 \%)$, Plutella xylostella (844, 2.52\%), Danaus plexippus (634, 1.89\%), Branchiostoma belcheri $(473,1.41 \%)$, and Papilio polytes (368, $1.10 \%)$ (Fig. 1).

Table 3

Functional annotation of the A. dissimilis transcriptomes.

\begin{tabular}{|lllll|}
\hline Database & Number & Rate $(\%)$ & $\mathbf{3 0 0} \leqq$ Length $<1000$ & Length $\geqq 1000$ \\
\hline COG & 6,712 & 19.37 & 2,638 & 4,074 \\
GO & 7,797 & 22.50 & 4,453 & 3,344 \\
\hline KEGG & 14,775 & 42.63 & 8,205 & 6,570 \\
\hline Pfam & 20,134 & 58.09 & 8,577 & 11,557 \\
\hline Swissprot & 15,174 & 43.78 & 6,987 & 8,187 \\
\hline eggNOG & 29,936 & 86.38 & 16,283 & 13,653 \\
\hline NR & 33,587 & 96.91 & 18,939 & 14,648 \\
\hline All & 34,658 & & 19,914 & 14,744 \\
\hline
\end{tabular}

For GO analysis, 7,797 unigenes (22.50\%) could be assigned to three GO terms including: cellular components (886 unigenes, $11.36 \%)$, molecular functions (5,683 unigenes, $72.89 \%$ ) and biological process (1,228 unigenes, $15.75 \%)$ (Fig. 2). The "molecular functions" were highest represented (72.89\% transcripts). For the "molecular functions" ontology, catalytic activity and binding were most prevalent.

\section{Identification of putative odorant-binding proteins}

In the A. dissimilis antennal and reproductive organ transcriptome, we identified 54 candidate OBPs (Genbank accession number: KR780027-KR780030, MH900289-MH900338), 31 of which were from the antennae (through the analysis of previous A. dissimilis antennal transcriptomes) and 23 from the testis and ovaries (Table 4). A total of 44 AdisOBP sequences had full-length ORFs. Their cDNAs encoded protein of 131-293 amino acids with molecular weights of 11.6-33.2 kDa and isoelectric points of 4.44-9.74. Excluding the 7 AdisOBPs (AdisOBP28, 30, 31, 35, 36, 41, 42, 52, 53 and 54) signal peptides were predicted at the N-terminus. AdisOBPs had 39-99\% sequence homology with previously identified OBPs from other insect species, displaying a high level of sequence similarity. For example, AdisOBP13 has a 95\% identity with Spodoptera exigua OBP9 (Table 1). A. dissimilis OBPs had only $11.87 \%$ identity. 
Table 4

The characteristic of candidate OBP genes in the antennae and reproductive organs of A. dissimilis.

\begin{tabular}{|c|c|c|c|c|c|c|c|c|c|c|}
\hline \multirow[t]{2}{*}{ Order } & \multirow[t]{2}{*}{ Gene name } & \multirow{2}{*}{$\begin{array}{l}\text { GenBank } \\
\text { accession } \\
\text { no. }\end{array}$} & \multirow{2}{*}{$\begin{array}{l}\text { ORF } \\
\text { (aa) }\end{array}$} & \multirow{2}{*}{$\begin{array}{l}\text { Molecular } \\
\text { weight(kD) }\end{array}$} & \multirow{2}{*}{$\begin{array}{l}\text { Isoelectric } \\
\text { point }\end{array}$} & \multirow{2}{*}{$\begin{array}{l}\text { Signal } \\
\text { peptide }\end{array}$} & \multirow{2}{*}{$\begin{array}{l}\text { Full } \\
\text { length }\end{array}$} & \multicolumn{3}{|c|}{ Homology search with the known proteins } \\
\hline & & & & & & & & $\begin{array}{l}\text { Gene } \\
\text { annotation }\end{array}$ & Species & Protein ID \\
\hline c69042 & AdisPBP1 & KR780029 & 166 & 17.32 & 5.19 & Yes & yes & PBP1 & $\begin{array}{l}\text { Mamestra } \\
\text { brassicae }\end{array}$ & AAC05702 \\
\hline c65047 & AdisPBP2 & KR780030 & 162 & 18.08 & 5.30 & Yes & Yes & PBP2 & $\begin{array}{l}\text { Mamestra } \\
\text { brassicae }\end{array}$ & AAC05701 \\
\hline c65143 & AdisPBP3 & MH900289 & 164 & 18.71 & 5.25 & Yes & yes & PBP3 & Agrotis ipsilon & AFM36758 \\
\hline c47645 & AdisGOBP1 & KR780027 & 163 & 18.89 & 5.19 & Yes & yes & GOBP1 & $\begin{array}{l}\text { Sesamia } \\
\text { inferens }\end{array}$ & AGS36742 \\
\hline c60029 & AdisGOBP2 & KR780028 & 161 & 18.09 & 5.09 & Yes & yes & GOBP2 & Agrotis ipsilon & AFM36760 \\
\hline c68783 & AdisOBP1 & MH900290 & 293 & 33.20 & 5.76 & Yes & yes & OBP & Bombyx mori & NP_001153663 \\
\hline c69959 & AdisOBP2 & МH900291 & 246 & 27.36 & 5.40 & Yes & yes & OBP10 & $\begin{array}{l}\text { Ostrinia } \\
\text { furnacalis }\end{array}$ & BAV56797 \\
\hline c60098 & AdisOBP3 & MH900292 & 145 & 16.22 & 8.37 & Yes & yes & OBP & $\begin{array}{l}\text { Spodoptera } \\
\text { exigua }\end{array}$ & ADY17886 \\
\hline c65852 & AdisOBP5 & MH900293 & 242 & 26.78 & 6.33 & Yes & yes & OBP35 & $\begin{array}{l}\text { Dendrolimus } \\
\text { punctatus }\end{array}$ & AR070194 \\
\hline c72710 & AdisOBP8 & MH900294 & 240 & 27.01 & 6.53 & Yes & Yes & OBP25 & $\begin{array}{l}\text { Spodoptera } \\
\text { exigua }\end{array}$ & AKT26502 \\
\hline c61153 & AdisOBP9 & MH900295 & 167 & 18.50 & 4.51 & Yes & Yes & OBP10 & $\begin{array}{l}\text { Sesamia } \\
\text { inferens }\end{array}$ & AGS36751 \\
\hline c60049 & AdisOBP11 & MH900296 & 141 & 16.38 & 4.47 & Yes & Yes & OBP8 & $\begin{array}{l}\text { Spodoptera } \\
\text { exigua }\end{array}$ & AGH70104 \\
\hline c65401 & AdisOBP13 & MH900297 & 133 & 15.14 & 9.01 & Yes & yes & OBP9 & $\begin{array}{l}\text { Spodoptera } \\
\text { exigua }\end{array}$ & AGH70105 \\
\hline c58306 & AdisOBP14 & MH900298 & 185 & 20.13 & 6.04 & Yes & Yes & OBP1 & Agrotis ipsilon & AGR39564 \\
\hline c64058 & AdisOBP15 & MH900299 & 146 & 16.43 & 6.29 & Yes & yes & OBP6 & Agrotis ipsilon & AGR39569 \\
\hline c53621 & AdisOBP16 & MH900300 & 118 & - & - & - & internal & OBP18 & $\begin{array}{l}\text { Spodoptera } \\
\text { exigua }\end{array}$ & AKT26496 \\
\hline c68160 & AdisOBP17 & MH900301 & 252 & 28.95 & 6.19 & Yes & Yes & OBP23 & $\begin{array}{l}\text { Spodoptera } \\
\text { exigua }\end{array}$ & AKT26500 \\
\hline c67912 & AdisOBP18 & MH900302 & 203 & 22.50 & 5.69 & Yes & Yes & OBP19 & $\begin{array}{l}\text { Helicoverpa } \\
\text { assulta }\end{array}$ & AGC92793 \\
\hline c60881 & AdisOBP19 & MH900303 & 139 & 14.55 & 8.58 & Yes & yes & OBP5 & Agrotis ipsilon & AGR39568 \\
\hline c71719 & AdisOBP20 & MH900304 & 139 & 15.69 & 7.52 & Yes & Yes & OBP8 & $\begin{array}{l}\text { Spodoptera } \\
\text { litura }\end{array}$ & AKI87969 \\
\hline c65033 & AdisOBP21 & MH900305 & 147 & 15.65 & 4.90 & Yes & Yes & OBP5 & $\begin{array}{l}\text { Helicoverpa } \\
\text { armigera }\end{array}$ & AEB54581 \\
\hline c63129 & AdisOBP22 & MH900306 & 146 & 15.92 & 7.53 & Yes & yes & OBP23 & $\begin{array}{l}\text { Spodoptera } \\
\text { litura }\end{array}$ & XP_022826767 \\
\hline c57331 & AdisOBP23 & MH900307 & 149 & 15.96 & 5.03 & Yes & yes & OBP26 & $\begin{array}{l}\text { Spodoptera } \\
\text { exigua }\end{array}$ & AKT26503 \\
\hline c64709 & AdisOBP24 & MH900308 & 148 & 16.77 & 5.45 & Yes & yes & OBP7 & $\begin{array}{l}\text { Helicoverpa } \\
\text { armigera }\end{array}$ & AEB54591 \\
\hline c81048 & AdisOBP25 & MH900309 & 71 & - & - & - & Internal & OBP22 & $\begin{array}{l}\text { Spodoptera } \\
\text { exigua }\end{array}$ & AKT26499 \\
\hline c53707 & AdisOBP26 & MH900310 & 134 & 14.28 & 4.51 & Yes & yes & OBP34 & $\begin{array}{l}\text { Helicoverpa } \\
\text { assulta }\end{array}$ & ASA40070 \\
\hline
\end{tabular}




\begin{tabular}{|c|c|c|c|c|c|c|c|c|c|c|}
\hline \multirow[t]{2}{*}{ Order } & \multirow[t]{2}{*}{ Gene name } & \multirow{2}{*}{$\begin{array}{l}\text { GenBank } \\
\text { accession } \\
\text { no. }\end{array}$} & \multirow{2}{*}{$\begin{array}{l}\text { ORF } \\
\text { (aa) }\end{array}$} & \multirow{2}{*}{$\begin{array}{l}\text { Molecular } \\
\text { weight(kD) }\end{array}$} & \multirow{2}{*}{$\begin{array}{l}\text { Isoelectric } \\
\text { point }\end{array}$} & \multirow{2}{*}{$\begin{array}{l}\text { Signal } \\
\text { peptide }\end{array}$} & \multirow{2}{*}{$\begin{array}{l}\text { Full } \\
\text { length }\end{array}$} & \multicolumn{3}{|c|}{ Homology search with the known proteins } \\
\hline & & & & & & & & $\begin{array}{l}\text { Gene } \\
\text { annotation }\end{array}$ & Species & Protein ID \\
\hline c28876 & AdisOBP27 & MH900311 & 124 & - & - & - & internal & OBP11 & $\begin{array}{l}\text { Spodoptera } \\
\text { exigua }\end{array}$ & AGP03457.1 \\
\hline c67118 & AdisOBP28 & MH900312 & 236 & 27.80 & 4.90 & No & yes & OBP9 & $\begin{array}{l}\text { Spodoptera } \\
\text { litura }\end{array}$ & ALD65883 \\
\hline c57589 & AdisOBP29 & МH900313 & 129 & - & - & - & $5^{\prime}$ lose & OBP33 & $\begin{array}{l}\text { Helicoverpa } \\
\text { assulta }\end{array}$ & ASA40072 \\
\hline c62521 & AdisOBP30 & MH900314 & 180 & 20.26 & 4.84 & No & yes & OBP9 & $\begin{array}{l}\text { Helicoverpa } \\
\text { armigera }\end{array}$ & AEB54592 \\
\hline c63839 & AdisOBP31 & MH900315 & 116 & 12.77 & 6.12 & No & yes & OBP14 & $\begin{array}{l}\text { Spodoptera } \\
\text { exigua }\end{array}$ & AGP03460 \\
\hline Gene.53346 & AdisOBP32 & МH900316 & 184 & 20.65 & 6.32 & Yes & Yes & GOBP70 & $\begin{array}{l}\text { Helicoverpa } \\
\text { armigera }\end{array}$ & XP_021188671 \\
\hline Gene.77161 & AdisOBP33 & МH900317 & 207 & 23.94 & 9.19 & Yes & Yes & OBP19 & $\begin{array}{l}\text { Helicoverpa } \\
\text { assulta }\end{array}$ & AGC92793 \\
\hline Gene. 60926 & AdisOBP34 & МH900318 & 193 & 22.42 & 5.48 & Yes & Yes & OBP9 & $\begin{array}{l}\text { Cnaphalocrocis } \\
\text { medinalis }\end{array}$ & ALT31639 \\
\hline Gene.32069 & AdisOBP35 & МH900319 & 137 & 15.34 & 8.85 & No & Yes & OBP & $\begin{array}{l}\text { Helicoverpa } \\
\text { armigera }\end{array}$ & AEX07279 \\
\hline Gene.44893 & AdisOBP36 & МH900320 & 143 & 15.92 & 5.57 & No & Yes & OBP19 & $\begin{array}{l}\text { Helicoverpa } \\
\text { assulta }\end{array}$ & AGC92793 \\
\hline Gene.35132 & AdisOBP37 & МH900321 & 102 & - & - & - & $5^{\prime}$ lose & OBP24 & $\begin{array}{l}\text { Cnaphalocrocis } \\
\text { medinalis }\end{array}$ & ALT31654 \\
\hline Gene.54044 & AdisOBP38 & МH900322 & 141 & 15.05 & 8.77 & Yes & Yes & OBP5 & Agrotis ipsilon & AGR39568 \\
\hline Gene.7082 & AdisOBP39 & МH900323 & 156 & 17.94 & 4.86 & Yes & Yes & PBP1 & $\begin{array}{l}\text { Helicoverpa } \\
\text { armigera }\end{array}$ & XP_021192649 \\
\hline Gene.113597 & AdisOBP40 & MH900324 & 166 & 19.09 & 8.61 & Yes & Yes & OВР38 & $\begin{array}{l}\text { Dendrolimus } \\
\text { punctatus }\end{array}$ & AR070197 \\
\hline Gene.77158 & AdisOBP41 & MH900325 & 141 & 16.29 & 9.12 & No & Yes & OBP19 & $\begin{array}{l}\text { Helicoverpa } \\
\text { assulta }\end{array}$ & AGC92793 \\
\hline Gene.14505 & AdisOBP42 & МH900326 & 102 & 11.15 & 5.44 & No & Yes & OBP23 & $\begin{array}{l}\text { Spodoptera } \\
\text { litura }\end{array}$ & ALD65897 \\
\hline Gene.54039 & AdisOBP43 & МH900327 & 76 & - & - & - & $5^{\prime}$ lose & OBP & $\begin{array}{l}\text { Helicoverpa } \\
\text { armigera }\end{array}$ & AEX07280 \\
\hline Gene.58201 & AdisOBP44 & МH900328 & 76 & - & - & - & $5^{\prime}$ lose & OBP23 & $\begin{array}{l}\text { Spodoptera } \\
\text { litura }\end{array}$ & ALD65897 \\
\hline Gene.32531 & AdisOBP45 & MH900329 & 150 & 16.43 & 4.77 & Yes & Yes & OBP2 & Agrotis ipsilon & AGR39565 \\
\hline Gene.5319 & AdisOBP46 & МH900330 & 70 & - & - & - & $5^{\prime}$ lose & OBP14 & $\begin{array}{l}\text { Spodoptera } \\
\text { exigua }\end{array}$ & AGP03460 \\
\hline Gene.86678 & AdisOBP47 & MH900331 & 120 & - & - & - & $5^{\prime}$ lose & OBP13 & $\begin{array}{l}\text { Sesamia } \\
\text { inferens }\end{array}$ & AGS36753 \\
\hline Gene.141496 & AdisOBP48 & МН900332 & 106 & 12.10 & 6.95 & No & Yes & OBP39 & $\begin{array}{l}\text { Dendrolimus } \\
\text { punctatus }\end{array}$ & AR070198 \\
\hline Gene.142856 & AdisOBP49 & MH900333 & 157 & 17.96 & 9.74 & Yes & Yes & OBP18 & $\begin{array}{l}\text { Dendrolimus } \\
\text { punctatus }\end{array}$ & AR070177 \\
\hline Gene.17592 & AdisOBP50 & MH900334 & 144 & 16.21 & 4.44 & Yes & Yes & OBP9 & $\begin{array}{l}\text { Helicoverpa } \\
\text { armigera }\end{array}$ & AEB54592 \\
\hline Gene.54647 & AdisOBP51 & MH900335 & 84 & - & - & - & $5^{\prime}$ lose & OBP39 & $\begin{array}{l}\text { Dendrolimus } \\
\text { punctatus }\end{array}$ & AR070198 \\
\hline Gene.76032 & AdisOBP52 & МH900336 & 105 & 11.60 & 4.71 & No & Yes & OBP & $\begin{array}{l}\text { Spodoptera } \\
\text { litura }\end{array}$ & ALD65897 \\
\hline Gene.111996 & AdisOBP53 & МН900337 & 105 & 12.28 & 8.21 & No & yes & OBP & $\begin{array}{l}\text { Operophtera } \\
\text { brumata }\end{array}$ & КОВ73304 \\
\hline
\end{tabular}




\begin{tabular}{|c|c|c|c|c|c|c|c|c|c|c|c|}
\hline \multirow{2}{*}{ Order } & \multirow[t]{2}{*}{ Gene name } & \multirow{2}{*}{$\begin{array}{l}\text { GenBank } \\
\text { accession } \\
\text { no. }\end{array}$} & \multirow{2}{*}{$\begin{array}{l}\text { ORF } \\
\text { (aa) }\end{array}$} & \multirow{2}{*}{$\begin{array}{l}\text { Molecular } \\
\text { weight(kD) }\end{array}$} & \multirow{2}{*}{$\begin{array}{l}\text { Isoelectric } \\
\text { point }\end{array}$} & \multirow{2}{*}{$\begin{array}{l}\text { Signal } \\
\text { peptide }\end{array}$} & \multirow{2}{*}{$\begin{array}{l}\text { Full } \\
\text { length }\end{array}$} & \multicolumn{3}{|c|}{ Homology search with the known proteins } & \\
\hline & & & & & & & & $\begin{array}{l}\text { Gene } \\
\text { annotation }\end{array}$ & Species & Protein ID & $:$ \\
\hline Gene.158529 & AdisOBP54 & MH900338 & 131 & 14.34 & 4.86 & No & yes & OBP11 & $\begin{array}{l}\text { Spodoptera } \\
\text { exigua }\end{array}$ & AGP03457 & \\
\hline
\end{tabular}

Multiple sequence alignments of the A. dissimilis OBPs revealed the presence of expected conserved cysteines (Fig. 3). The phylogenetic tree of A. dissimilis and other lepidopteran OBPs constructed using the neighbor-joining method, indicated five clades that contained four possible protein subfamilies (Fig. 4). In addition, the tree showed low levels of clustering highlighting the diversity of the lepidopteran OBPs. Five (AdisPBP1-3, GOBP1-2) AdisOBPs belonged to PBP/GOBP. A total of 35 OBPs (AdisOBP1, 3-5, 6-10, 12-17, 19-22) were 'Classic' OBPs that contained six positionally-conserved cysteine residues. Seven OBPs (AdisOBP14-16, 18, 33, 36 and 41) belonged to 'Plus-C' subclass OBP genes. Nine OBPs belonged to 'Minus-C' subclass OBP genes. Interestingly, AdisOBP1, AdisOBP17 and AdisOBP40 did not belong to any of the four protein subfamilies (Fig. 4). The transcription abundance of A. dissimilis OBPs in antennae of female and males, ovary and testis are profiled in Fig. 5.

\section{Expression of the OBPs in the antennae, ovaries and testis of A. dissimilis}

To understand the functions of the identified OBPs in A. dissimilis, we measured the relative expression levels of OBPs in different tissues of A. dissimilis via fluorescence qRT-PCR (Fig. 6). A total of 23 OBPs (AdisGOBP1-2, PBP1-3, OBP1-2, 8-9, 11, 17, 20-22, 24, 26-31, 50 and 54) were highly expressed in both female and male antennae compared to the reproductive organs of females and males. A total of 5/23 OBPs (Adis GOBP1, OBP8-9, 24 and 29) showed comparable expression in the male and female antennae of A. dissimilis; 3/23 (AdisPBP1, OBP17 and OBP26) were higher in males; and 15/23 were higher in females.

A total of 24 OBPs (AdisOBP3, 5, 15, 18-19, 23, 25, 33-41, 44-45, 47-49 and 51-53) were highly expressed in the testis of A. dissimilis compared to other tissues. The expressive of the OBPs were low in the ovaries of $A$. dissimilis.

\section{Discussion}

Insects rely on peripheral sensilla on the antennae to distinguish plant odorants and pheromones [31], ${ }^{37}$ a knowledge of the molecular mechanisms of olfaction is essential for better using olfactory-based pest management strategies and the development of novel strategies. OBPs are more accessible targets for research, considering they are small, soluble, stable and easier to manipulate and modify. About exact functions of the OBPs are unclear, but it is widely believed that their function is to capture and transfer outside odorants to ORs located on the membranes of ORNs [8, 11, 32]. ${ }^{8,11,38}$ Insect OBPs are present on the antennae where they execute odorant functions [11,33-36]. ${ }^{11,39-42}$ In this study, we identified 31 novel OBPs through the analysis of A. dissimilis antennal transcriptomes, expressing five previously reported AdisOBPs [30]. ${ }^{30}$ The number of OBPs in A. dissimilis antennae were similar to the antennal transcriptomes of S. litura (33) [37] $]^{43}$ and S. littoralis (36) [38] ${ }^{44}$ but more abundant than S. exigua (11) [39] $]^{45}$, M. sexta (18) [40] $]^{46}$ and H. armigera (26) $[41]{ }^{47}$ We additionally sequenced the transcriptomes of A. dissimilis ovaries and testis. The alignments against the Nr database showed that $56.87 \%$ of the A. dissimilis unigenes were comparable to Helicoverpa armigera sequences. A total of 24 OBPs were identified in the transcriptomes of A. dissimilis reproduction organs.

Based on the cluster analysis of the phylogenetic trees, five AdisOBPs belonged to PBP/GOBP; 35 AdisOBPs belonged to 'Classic' OBPs; 7 AdisOBPs belonged to 'Plus-C' OBPs; and 9 AdisOBPs belonged to 'Minus-C' OBPs. These results were similar to the classifications of most insect OBPs [25, 37, 42]. ${ }^{25,43,48}$ Interestingly, AdisOBP1, AdisOBP17 and AdisOBP40 did not cluster into these 4 protein subfamilies, but multiple sequence alignments of the A. dissimilis OBPs revealed that 3 of the OBPs contain no conserved cysteines. Their construction requires further to verification.

Insect OBPs are expressed in the sensory organs $[22,25,37,43-45] .22,25,43,49-51$ Our result showed that 23 AdisOBPs were significantly expressed in both female and male antennae compared to other tissues. Only the expression of 3 AdisOBPs were significantly higher in the antennae's of males compared to females, suggesting that females require more abundant OBPs for spawning. OBPs are also expressed in the non-olfactory organs, such as those required for reproduction [24-25.46-48]. ${ }^{24-25,52-54}$ In this study, 24 AdisOBPs showed significant expression in the testis of A. dissimilis compared to other tissues, but the expression of AdisOBPs in the ovaries were low. It was previously speculated that OBPs expressed in the testis deliver compounds to the females during mating [24-25]. ${ }^{24-25}$ Hence, it is understandable to presume that such stable proteins could be used in the testis of insect where there is need for transportation of hydrophobic molecules in aqueous media or protection of chemicals from degradation, as well as to assure a gradual release of semiochemicals in the environment. So these proteins have been named for "encapsulins", to imply the common role of encapsulating small ligands [49]. ${ }^{55}$

\section{Conclusions}

In summary, we demonstrate that the A. dissimilis chemosensory genes show functional diversity. These findings enhance our knowledge of the roles of OBPs in A. dissimilis and lepidopteran species and provide a base for studying OBPs novel targets of pest management strategies.

\section{Methods}




\section{Insect rearing and sample preparation}

The A. dissimilis strain was collected from Luoyang (province of Henan, China) corn fields $\left(112^{\circ} 26^{\prime} \mathrm{E}, 34^{\circ} 43^{\prime} \mathrm{N}\right)$ in 2014 and maintained at the Henan Science and Technology University. Colonies were reared on an artificial diet at $25 \pm 1{ }^{\circ} \mathrm{C}, 80 \pm 5 \%$ relative humidity and a 16 -h/8-h light/dark cycle.

Based on preliminary data, we found that the A. dissimilis sperm and eggs began to mature 3 days after emergence. We respectively collected the ovaries and testes of 3-day old virgin females and male adults $(n=40$ per treatment) from three biological replications. Dissections were performed in sterile PBS-DEPC and immediately frozen in liquid nitrogen until RNA isolation.

\section{cDNA library preparation and sequencing}

Total RNA from the A. dissimilis ovaries and testis tissues were extracted using RNAiso Plus kit (TaKaRa, Dalian, China) and treated with DNase I (TaKaRa, Dalian, China) as per the manufacturer's protocols. RNA was assessed through $1 \%$ agarose gel electrophoresis and Nanodrop $2000 \AA$ (Thermo Scientific, Waltham, MA, USA), Qubit 2.0 (Life Technologies, Carlsbad, CA, USA) and Agilent 2100 (Agilent, Santa Clara, CA, USA) analysis.

Following the TruSeq RNA Sample Preparation Guide v2 (Illumina, San Diego, CA, USA), mRNA was enriched using magnetic beads crosslinked with Oligo (dT). Enriched RNA was then fragmented using fragmentation buffer and first-strand cDNA synthesis was used to produce small mRNA fragments, random primers, reverse transcriptase, and second-strand cDNA synthesis through the addition of dNTPs, DNA polymerase I, and RNase H. Double-stranded cDNA was purified with AMPure XP beads (Beckman Coulter, Brea, CA, USA) and treated to repair ends, remove poly(-A) tails, and link sequencing adapters. Fragment sizes were selected using AMPure XP beads and cDNA libraries were constructed through PCR amplification (Veriti $\rightarrow$ 96-Well Thermal Cycle, Applied Biosystems, Foster City, USA). The concentration and insert size of the cDNA libraries were detected using Qubit 2.0 and Agilent 2100 and quantified via q-PCR (CFX-96, Bio-Rad, Hercules, CA, USA).

Finally, sequencing was performed using the Illumina $\mathrm{HiSeq}^{\mathrm{TM}} 4000$ platform to generate 150 -bp paired-end reads. Sequencing analyses were performed by the Genomics Services of the Beijing Biomarker Technologies Co., Ltd. (Beijing, China). Raw data processing and base calling were performed using Illumina software.

\section{Assembly and Functional annotation}

Raw data (raw reads) in the FASTQ format were first modified into clean data (clean reads) through Perl scripts. This was performed through the removal of reads containing adapter sequences, $>10 \%$ unknown nucleotides and quality values $\leq 20$. The Q20, Q30, and GC content were then calculated using highquality data.

Transcriptomes were assembled using Trinity (version trinityrnaseq_r20131110) with default settings, except for min_kmer_cov set to 2 [50]. ${ }^{31}$ Unigene functions were annotated based on NCBI non-redundant protein sequences (NR, NCBI blast 2.2.28+, e-value = 1e-5), NCBI nucleotide sequences (NT, NCBI blast 2.2.28+, e-value = 1e-5), Protein family (Pfam, HMMER 3.0 package, hmmscan, e-value = 0.01), eukaryotic Ortholog Groups (KOG, NCBI blast 2.2.28+, e-value = 1e-3), SwissProt (NCBI blast 2.2.28+, e-value = 1e-5), the Kyoto Encyclopedia of Genes and Genomes (KEGG; KEGG Automatic Annotation Server [KASS], evalue $=1 \mathrm{e}-10)$ and Gene Ontology (GO, Blast2GO v2.5, e-value $=1 \mathrm{e}-6)$. Coding sequences (CDS) were predicted through aligning transcriptome sequences to the $\mathrm{Nr}$ and Swiss-Prot database or using estscan 3.0.3 [51]. ${ }^{32}$

\section{Sequence and phylogenetic analysis}

Sequence similarities were assessed using the NCBI-Blast network server (http://blast.ncbi.nlm.nih.gov/). The signal peptides of OBPs were predicted using SignalP 4.1 (http://www.cbs.dtu.dk/services/SignalP/) [52]. ${ }^{33}$ Multiple sequence alignments were assessed using DNAMAN 6.0. Sequence alignments of the candidate OBPs were performed using ClustalX $2.1[53]^{34}$ and used to construct phylogenetic trees with PhyML in Seaview v.4 based on the Jones-TaylorThormton (JTT) model with nearest-neighbor interchanges. Trees were viewed and edited using FigTree v.1.3.1.

\section{Transcript expression profiling}

Sequencing Reads were compared to the Unigene libraries using Bowtie, and expression levels were estimated by combining RSEM. FPKM values are used to represent the expression abundance of the corresponding Unigenes [54]. ${ }^{35}$ Averages of three biological replicates as the actual expression values for each transcript were obtained. Based on the RNA-seq data, tissue-specific expression of the OBPs were profiled.

\section{Expression analysis through quantitative real-time polymerase chain reaction}

Male antennae, female antennae, ovaries and testes tissue from adults at 3 post-eclosion were excised and frozen in liquid nitrogen. Total RNA was extracted using RNAiso Plus kits (TaKaRa, Dalian, China) and isolated RNA was transcribed to first-strand cDNA using PrimeScript ${ }^{\text {TM }}$ RT reagent with gDNA Eraser (TaKaRa, Dalian, China) following the manufacturer's protocols. Real-time quantitative PCR (RT-qPCR) was performed with SYBRß Premix Ex Taq ${ }^{\text {TM }}$ II (TaKaRa). The A. dissimilis GADPH gene was used as an endogenous control to correct for sample-to-sample variations. A $200 \mathrm{ng} / \alpha \mathrm{L} c D N A$ sample was used for per tissue. Primers were designed using Primer Premier 5.0 software and are listed in supportment Table 1. RT-qPCR reactions contained: $10 \mu \mathrm{L}$ of SYBR Premix Ex Taq II, $20 \mathrm{ng}$ of cDNA template, $0.2 \mu \mathrm{M}$ of each primer and nuclease-free water. The cycling conditions were $1 \mathrm{cycle}$ of $95^{\circ} \mathrm{C}$ for 5 min, followed by 40 cycles of $95^{\circ} \mathrm{C}$ for $5 \mathrm{~s}$ and $55^{\circ} \mathrm{C}$ for $30 \mathrm{~s}$. Melt curve conditions were $95^{\circ} \mathrm{C}$ for $10 \mathrm{~s}$ and $65^{\circ} \mathrm{C}$ for $30 \mathrm{~s}$. No-template controls (NTC) were included to detect possible contamination. Three biological replicates were analyzed and the relative expression of the OBP genes across the samples were measured using the $2^{-\Delta \Delta C T}$ method [55]. ${ }^{36}$ Expression was calculated relative to levels in the female antennae, which were arbitrarily set to 1 . Differences in the expression of AdisOBP genes between the different tissues were compared using a one-way nested analysis of variance (ANOVA), followed by a Tukey's honestly significance difference (HSD) test using SPSS (SPSS Institute 17.0, SPSS Inc, Chicago, IL, USA).

Page $7 / 15$ 


\section{Abbreviations}

CO:Carbon dioxide; FPKM:Fragments per kb per million fragments; GO:Gene ontology; GR:Glutamate receptor; iGluR:Ionotropic glutamate receptor; IR:Ionotropic receptor; JTT:Jones-Taylor-Thornton amino acid substitution model; OR:Odorant receptor; ORF:Open reading frame; TMD:Transmembrane domain.

\section{Declarations}

\section{Funding}

This study is supported by the National Natural Science Foundation of China (31701788 to YS) and the Natural Science Foundation of Henan Province of China (182300410024 to HS).

\section{Availability of data and materials}

All data generated or analysed during this study are included in this published article [and its supplementary information files].

\section{Authors' contributions}

All authors contributed to research design and manuscript preparation. Conceived and designed the experiments: YS, HS, JZ. Performed the experiments: YS, HS, JZ. Analyzed the data: YS, HS, JZ. Contributed reagents/materials/analysis tools: YS, JZ. Wrote the paper: YS, HS. All authors read and approved the final manuscript.

\section{Consent for publication}

Not applicable.

\section{Ethics approval and consent to participate}

Not applicable.

\section{Competing interests}

The authors declare that they have no competing interests.

\section{Author details}

${ }^{1}$ Forestry College, Henan University of Science and Technology, Luoyang 471000, China. ${ }^{2}$ Zhumadian Academy of Agricultural Sciences, Zhumadian 463000, China

\section{References}

1. Field LM, Pickett JA, Wadhams LJ. Molecular studies in insect olfaction. Insect Mol Biol. 2000; 9: 545-51.

2. Zhan S, Merlin C, Boore JL, Reppert SM. The monarch butterfly genome yields insights into long-distance migration. Cell. 2011; 147: 1171-85.

3. Suh E, Bohbot J, Zwiebel LJ. Peripheral olfactory signaling in insects. Curr Opin Insect Sci. 2014; 6: 86-92.

4. Sun L, Xiao HJ, Gu SH, Guo YY, Liu ZW, Zhang YJ. Perception of potential sex pheromones and host-associated volatiles in the cotton plant bug, Adelphocoris fasciaticollis (Hemiptera: Miridae): morphology and electrophysiology. Appl Entomol Zool. 2014; 49: 43-57.

5. Zhang J, Walker WB, Wang G. Pheromone reception in moths: from molecules to behaviors. Prog Mol Biol Transl Sci. 2015; 130: 109-28.

6. Getchell TV, Margolis FL, Getchell ML. Perireceptor and receptor events in vertebrate olfaction. Prog Neurobiol. 1984; 23: 317-45.

7. Du G, Prestwich GD. Protein structure encodes the ligand binding specificity in pheromone binding proteins. Biochemistry. $1995 ; 34: 8726-32$.

8. Pelosi P, Zhou JJ, Ban L, Calvello M. Soluble proteins in insect chemical communication. Cell Mol Life Sci. 2006; 63: 1658-76.

9. Fan J, Francis F, Liu Y, Chen JL, Cheng DF. An overview of odorant-binding protein functions in insect peripheral olfactory reception. Genet Mol Res. 2011; 10: 3056-69.

10. Tunstall NE, Warr CG. Chemical communication in insects: the peripheral odor coding system of Drosophila melanogaster. Adv Exp Med Biol. 2012; 739: 59-77.

11. Leal WS. Odorant reception in insects: Roles of receptors, binding proteins, and degrading enzymes. Annu Rev Entomol. $2013 ; 58: 373-91$.

12. Vogt RG, Riddiford LM. Pheromone binding and inactivation by moth antennae. Nature, 1981; 293: 161-3.

13. Pelosi P, Maida R. Odorant-binding proteins in insects. Comp Biochem Phys B. 1995; 111: 503-14.

14. Angeli S, Ceron F, Scaloni A, Monti M, Monteforti G, Minnocci A, et al. Purification, structural characterization, cloning and immunocytochemical localization of chemoreception proteins from Schistocerca gregaria. Eur J Biochem. 1999; 262:745-54.

15. Leal WS, Nikonova L, Peng G. Disulfide structure of the pheromone binding protein from the silkworm moth, Bombyx mori. FEBS Letters. 1999; 464: 8590.

16. Zhou JJ. Odorant-binding proteins in insects. Vitamins \& Hormones. 2010; 83: 241-72. 
17. Lagarde A, Spinelli S, Tegoni M, He X, Field L, Zhou JJ, et al. The crystal structure of odorant binding protein 7 from Anopheles gambiae exhibits an outstanding adaptability of its binding site. J Mol Biol. 2011; 414: 401-12.

18. Cao DP, Liu Y, Wei JJ, Liao XY, Walker WB, Li JH, et al. Identification of candidate olfactory genes in Chilo suppressalis by antennal transcriptome analysis. Int J Biol Sci. 2014; 10: 846.

19. Zhang SF, Zhang Z, Wang HB, Kong XB. Antennal transcriptome analysis and comparison of olfactory genes in two sympatric defoliators, Dendrolimus houi and Dendrolimus kikuchii (Lepidoptera: Lasiocampidae). Insect Biochem Molec. 2014; 52: 69-81.

20. Jia XJ, Wang HX, Yan ZG, Zhang MZ, Wei CH, Qin XC, et al. Antennal transcriptome and differential expression of olfactory genes in the yellow peach moth, Conogethes punctiferalis (Lepidoptera: Crambidae). Sci Rep. 2016; 6: 29067.

21. Pregitzer P, Zielonka M, Eichhorn AS, Jiang X, Krieger J, Breer H. Expression of odorant-binding proteins in mouthpart palps of the desert locust Schistocerca gregaria. Insect Mol Biol. 2019; 28: 264-76.

22. Cheng WN, Zhang YD, Liu W, Li GW, Zhu-Salzman K. Molecular and functional characterization of three odorant-binding proteins from the wheat blossom midge, Sitodiplosis mosellana. Insect Sci. 2019; 98: e21456.

23. Yin J, Wang CQ, Fang CQ, Zhang S, Cao YZ, Li KB, et al. Functional characterization of odorant-binding proteins from the scarab beetle Holotrichia oblita based on semiochemical-induced expression alteration and gene silencing. Insect Biochem Molec. 2019; 104: 11-9.

24. Li S, Picimbon JF, Ji SD, Kan YC, Qiao CL, Zhou JJ, et al. Multiple functions of an odorant-binding protein in the mosquito Aedes aegypti. Biochem Bioph Res Co. 2008; 372(3): 464-8.

25. Sun YL, Huang LQ, Pelosi P, Wang CZ. Expression in antennae and reproductive organs suggests a dual role of an odorant-binding protein in two sibling Helicoverpa species. PLoS ONE. 2012; 7: e30040.

26. Li JW, Yu Y, Zhang AS, Men XY, Zhou XH, Zhai YF, et al. Morphologically a like species of Athetis lepigone (Möschler) - A. dissimilis (Hampson) found in Shandong Province of China. Plant Prot. 2014; 40(6): 193-5.

27. Takahashi M. Athetis dissimilis Hampson, a new nuisance? Jpn Soc Med Entomol Zool. 1975; $26: 66$.

28. Li NG. Relationships between cold hardiness and ice nucleating activity, glycerol and protein contents in the hemolymph of caterpillars, Aporia crataegi L. CryoLetters. 2012; 33: 134-42.

29. Dong J, Song Y, Li W, Shi J, Wang Z. Identification of putative chemosensory receptor genes from the Athetis dissimilis antennal transcriptome. PLoS ONE. 2016; 11(1): e0147768.

30. Sun HZ, Song YQ, Du J, Wang XD, Cheng ZJ. Identification and tissue distribution of chemosensory protein and odorant binding protein genes in Athetis dissimilis (Lepidoptera: Noctuidae). Appl Entomol Zool. 2016; 51(3): 409-20.

31. Olsson POC, Anderbrant O, Löfstedt C, Borg-Karlson AK, Liblikas I. Electrophysiological and behavioral responses to chocolate volatiles in both sexes of the pyralid moths Ephestia cautella and Plodiainterpunctella. J Chem Ecol. 2005; 31: 2947-61.

32. Liu Z, Smagghe G, Lei ZR, Wang JJ. Identification of male-and female-specific olfaction genes in antennae of the oriental fruit fly (Bactrocera dorsalis). PloS ONE. 2016; 11: e0147783.

33. Qiao H, Tuccori E, He X, Gazzano A, Field L, Zhou JJ, et al. Discrimination of alarm pheromone (E)-beta-farnesene by aphid odorant-binding proteins. Insect Biochem Molec. 2009; 39(5-6): 414-19.

34. Zhou JJ, Robertson G, He X, Dufour S, Hooper AM, Pickett JA, et al. Characterisation of Bombyx mori Odorant-binding proteins reveals that a general odorant-binding protein discriminates between sex pheromone components. J Mol Biol. 2009; 389(3): 529-45.

35. Larter NK, Sun JS, Carlson JR. Organization and function of Drosophila odorant binding proteins. Elife. 2106; 5: e20242.

36. Jia X, Zhang X, Liu H, Wang R, Zhang T. Identification of chemosensory genes from the antennal transcriptome of Indianmeal moth Plodiainter punctella. PLoS ONE. 2018; 13: e0189889.

37. Gu SH, Zhou JJ, Gao S, Wang DH, Li XC, Guo YY. et al. Identification and comparative expression analysis of odorant binding protein genes in the tobacco cutworm Spodoptera litura. Sci Rep-UK. 2015; 5: 13800.

38. Poivet E, Gallot A, Montagné N, Glaser N, Legeai F, Jacquin-Joly E. A comparison of the olfactory gene repertoires of adults and larvae in the noctuid moth Spodoptera littoralis. PLoS ONE. 2013; 8: e60263.

39. Zhu JY, Zhang LF, Ze SZ, Wang DW, Yang B. Identification and tissue distribution of odorant binding protein genes in the beet armyworm, Spodoptera exigua. J Insect Physiol. 2013; 59(7): 722-8.

40. Grosse-Wilde E, Kuebler LS, Bucks S, Vogel H, Wicher D, Hansson BS. Antennal transcriptome of Manduca sexta. Proc Natl Acad Sci. 2011 ; 108 : $7449-54$.

41. Liu Y, Gu SH, Zhang YJ, Guo YY, Wang GR. Candidate olfaction genes identified within the Helicoverpa armigera antennal transcriptome. PloS ONE. 2012; 7: e48260.

42. Chang H, Ai D, Zhang J, Dong S, Liu Y, Wang G. Candidate odorant binding proteins and chemosensory proteins in the larval chemosensory tissues of two closely related noctuidae moths, Helicoverpa armigera and $H$. assulta. PLoS ONE. 2017; 12(6): e0179243.

43. Feng B, Guo QS, Zheng KD, Qin YX, Du YJ. Antennal transcriptome analysis of the piercing moth Oraesia emarginata (Lepidoptera: Noctuidae). PloS ONE. 2017; 12(6): e0179433.

44. Wei HS, Li KB, Zhang S, Cao YZ, Yin J. Identification of candidate chemosensory genes by transcriptome analysis in Loxostege sticticalis Linnaeus. PloS ONE. 2017; 12(4): e0174036.

45. Tian ZQ, Sun LN, Li YY, Quan LF, Zhang HJ, Yan WT, et al. Antennal transcriptome analysis of the chemosensory gene families in Carposina sasakii (Lepidoptera: Carposinidae). BMC Genomics. 2018; 19: 544.

Page 9/15 
46. Zhang TT, Coates BS, Ge X, Bai SX, He KL, Wang ZY. Male-and female-biased gene expression of olfactory-related genes in the antennae of Asian corn borer, Ostrinia furnacalis (Guene'e) (Lepidoptera: Crambidae). PloS ONE. 2015; 10(6): e0128550.

47. Song LM, Jiang X, Wang XM, Li JD, Zhu F, Tu XB, et al. Male tarsi specific odorant-binding proteins in the diving beetle Cybister japonicus sharp. Sci RepUK. 2016; 6: 31848.

48. Chen XF, Xu L, Zhang YX, Wei D, Wang JJ, Jiang HB. Genome-wide identification and expression profiling of odorant-binding proteins in the oriental fruit fly, Bactrocera dorsalis. Comp Biochem Phys D. 2019; 31: 100605.

49. Leal WS. Molecular-based chemical propecting of mosquito attractants and repellents. In: Debboun MF, Strickman D (Eds.), Insect Repellents: Principles, Methods, and Uses. CRC Press. 2006; pp. 229-244.

50. Grabherr MG, Haas BJ, Yassour M, Levin JZ, Thompson DA, Amit I. et al. Full-length transcriptome assembly from RNA-Seq data without a reference genome. Nat Biotechnol. 2011; 29(7): 644-52.

51. Iseli C, Jongeneel CV, Bucher P. ESTScan: a program for detecting, evaluating, and reconstructing potential coding regions in EST sequences. Proc Int Conf Intell Syst Mol Biol. 1999; 7: 138-48.

52. Petersen TN, Brunak S, von Heijne G, Nielsen H. SignalP 4.0: discriminating signal peptides from transmembrane regions. Nature Methods. 2011; 8: 7856.

53. Larkin M, Blackshields G, Brown N, Chenna R, McGettigan PA, McWilliam H, et al. Clustal W and Clustal X version 2.0. Bioinformatics. 2007; 23(21): 294748.

54. Mortazavi A, Williams BA, McCue K, Schaeffer L, Wold B. Mapping and quantifying mammalian transcriptomesby RNA-Seq. Nat Methods. 2008 ; 5: $621-8$.

55. Livak KJ, Schmittgen TD. Analysis of relative gene expression data using real-time quantitative PCR and the 2(T) $(-\triangle \Delta C)$ method. Methods. 2001; 25 : 402-8.

\section{Figures}

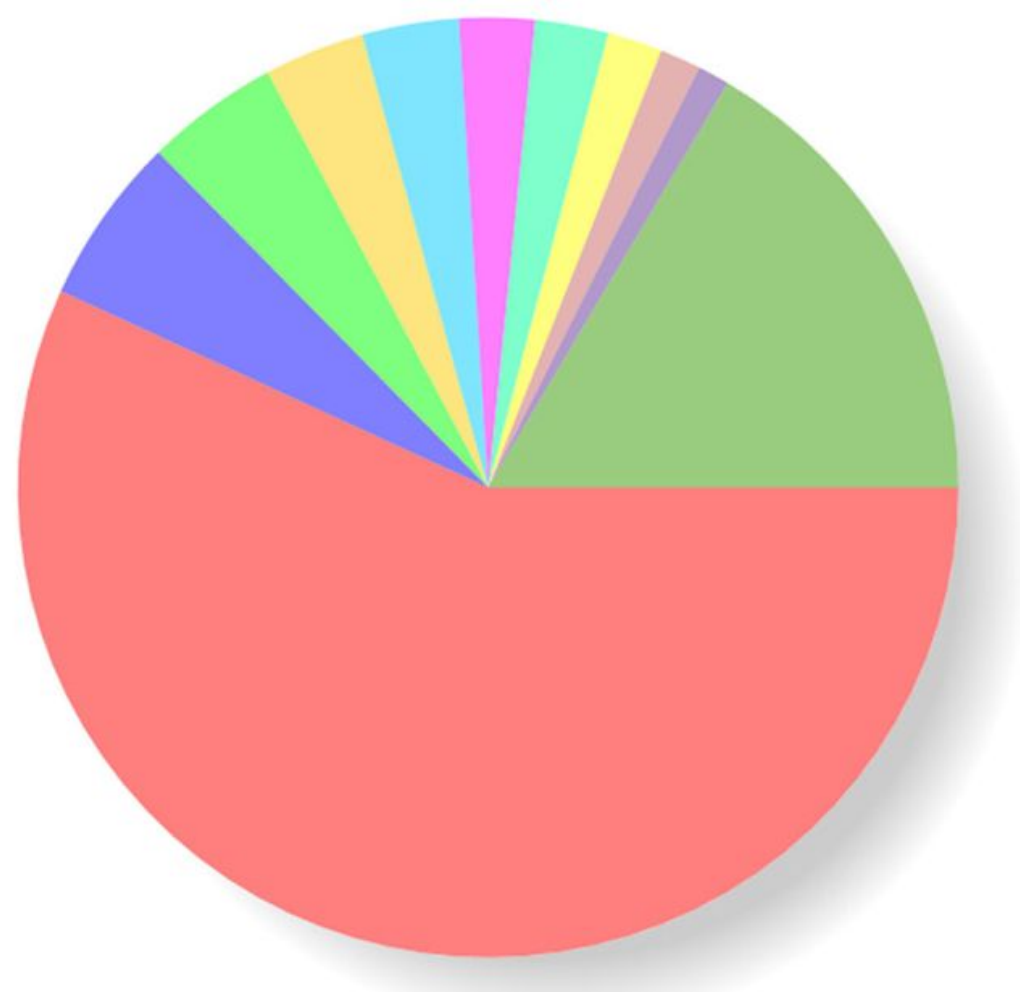

Helicoverpa armigera [19072 56.87\%]

Amyelois transitella [1936 5.77\%]

Bombyx mori [1543 4.60\%]

Papilio machaon [1155 3.44\%]

Operophtera brumata [1116 3.33\%]

Papilio xuthus [868 2.59\%]

Plutella xylostella [844 2.52\%]

Danaus plexippus [634 1.89\%]

Branchiostoma belcheri [473 1.41\%]

Papilio polytes [368 1.10\%]

Other [5530 16.49\%]

Figure 1

The Blastx results of $A$. dissimilis reproductive organs unigenes in NR database. 


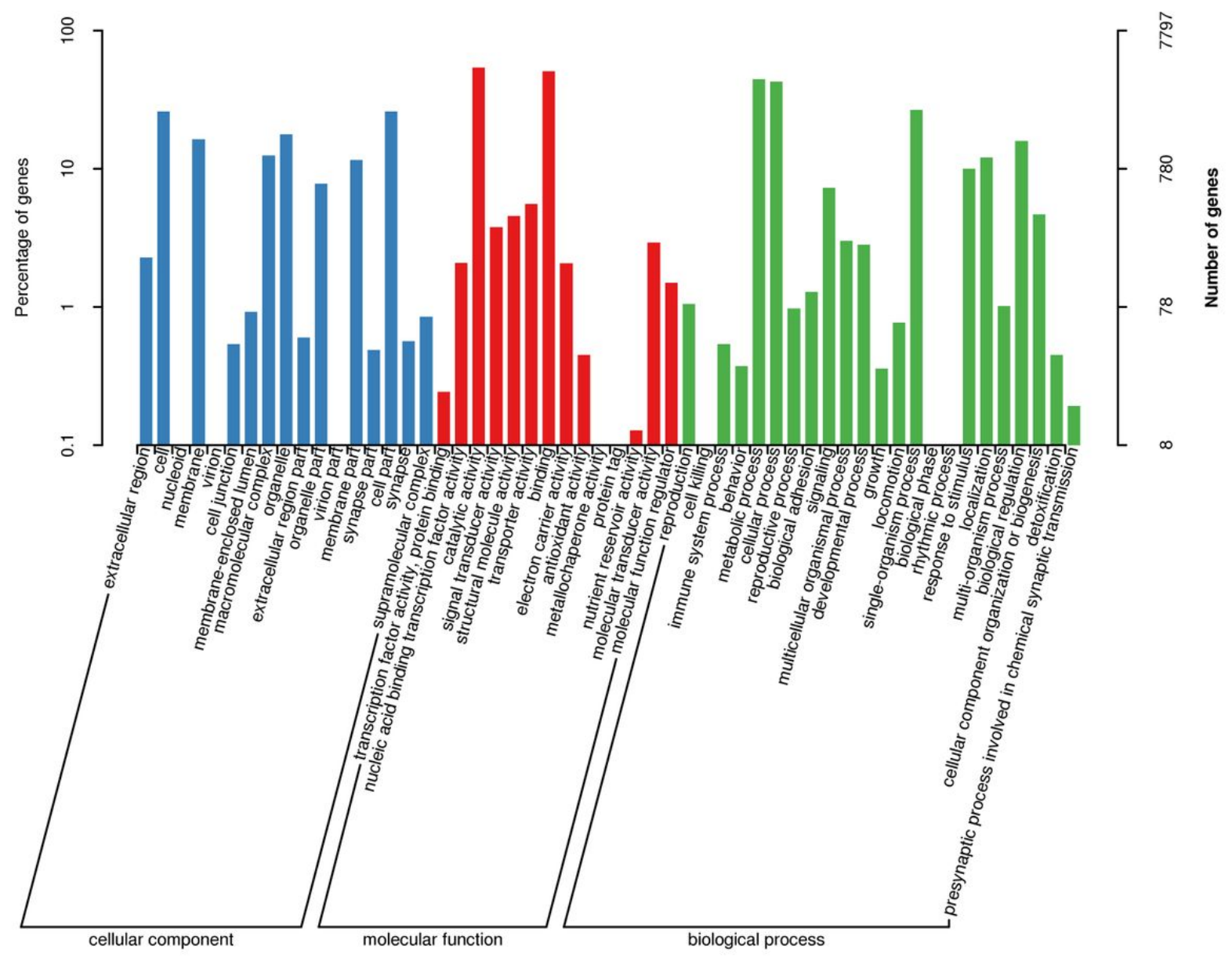

Figure 2

Gene Ontology (GO) classifications of A. dissimilis reproductive organs unigenes according to their involvement in biological processes, cellular component and molecular function. 


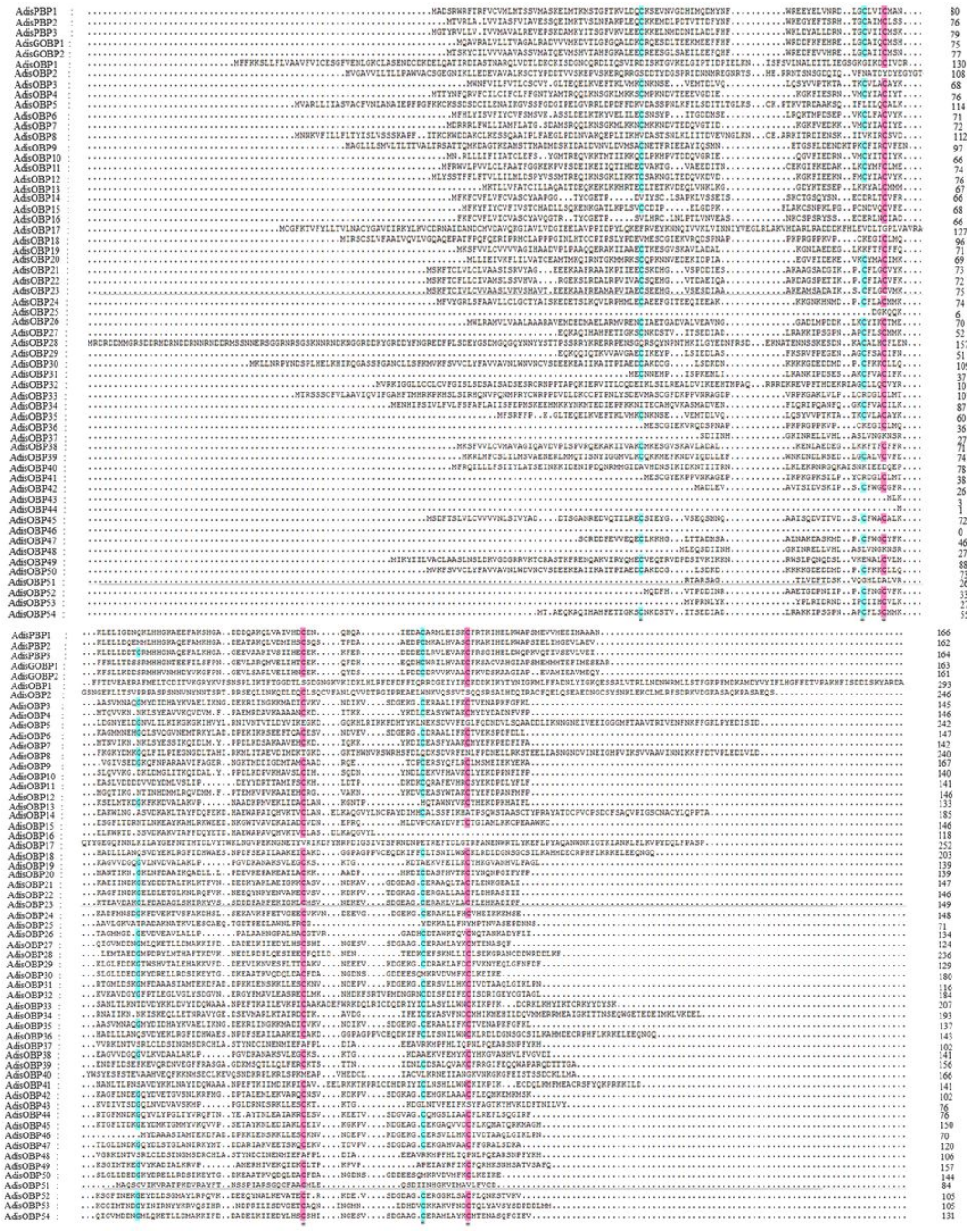

Figure 3

Sequence alignments of A. dissimilis OBPs. 


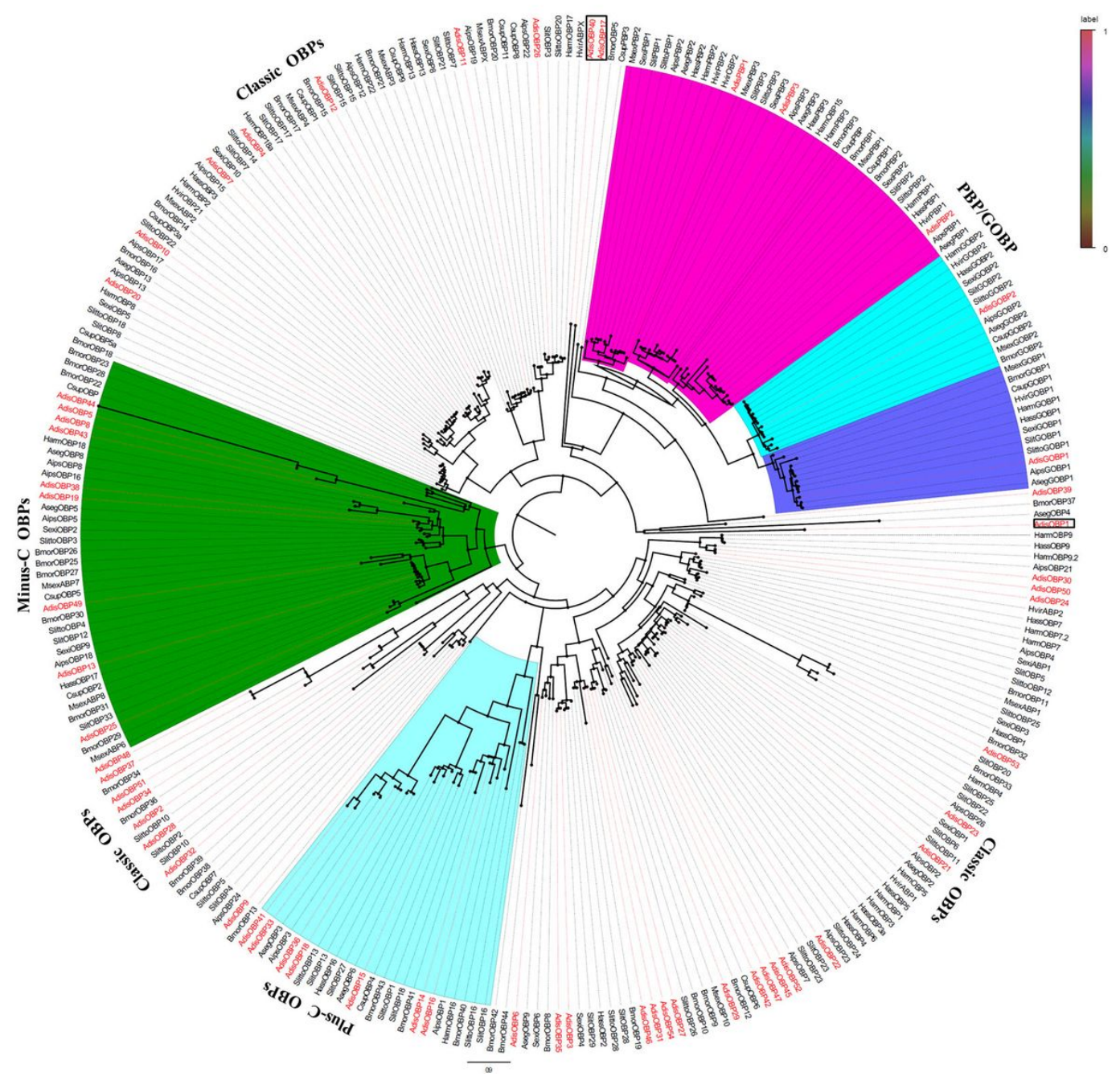

Figure 4

Phylogenetic relationships of candidate OBP proteins from A. dissimilis and Lepidoptera species. 


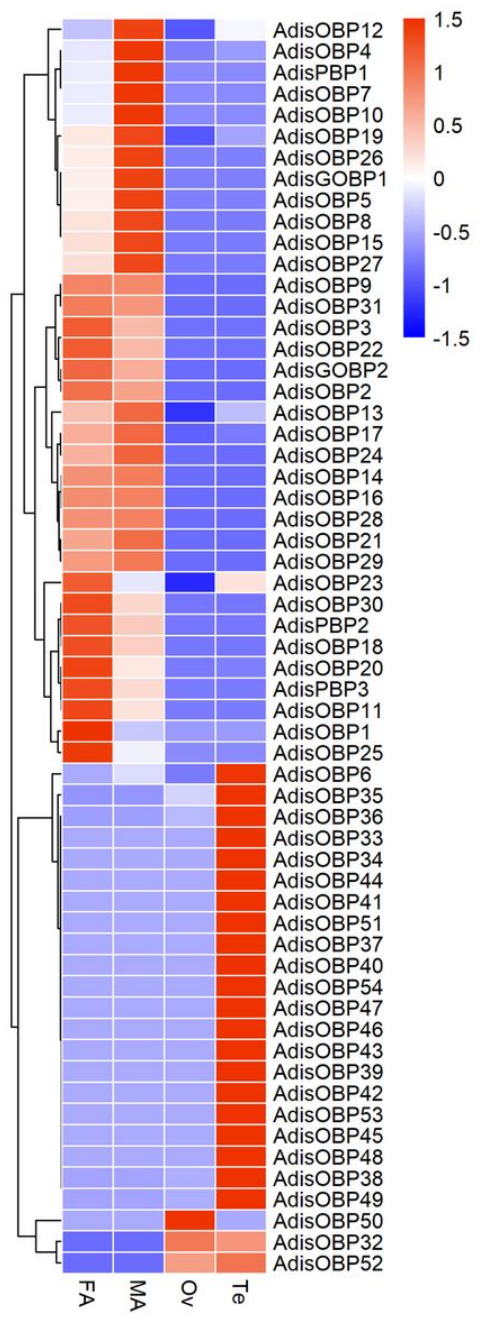

\section{Figure 5}

Heat map showing the abundance of unigenes encoding OBPs in the A. dissimilis different tissues transcriptomes presented as normalized reads in reads per kilobase per million mapped reads (RPKM). In the figure each column represents 1 samples; each line represents 1 OBP gene. The color depth represents the number of reads contained in OBPs; red means more; blue means less. FA: female antennae; MA: male antennae; Ov: ovaries; Te: testis. 


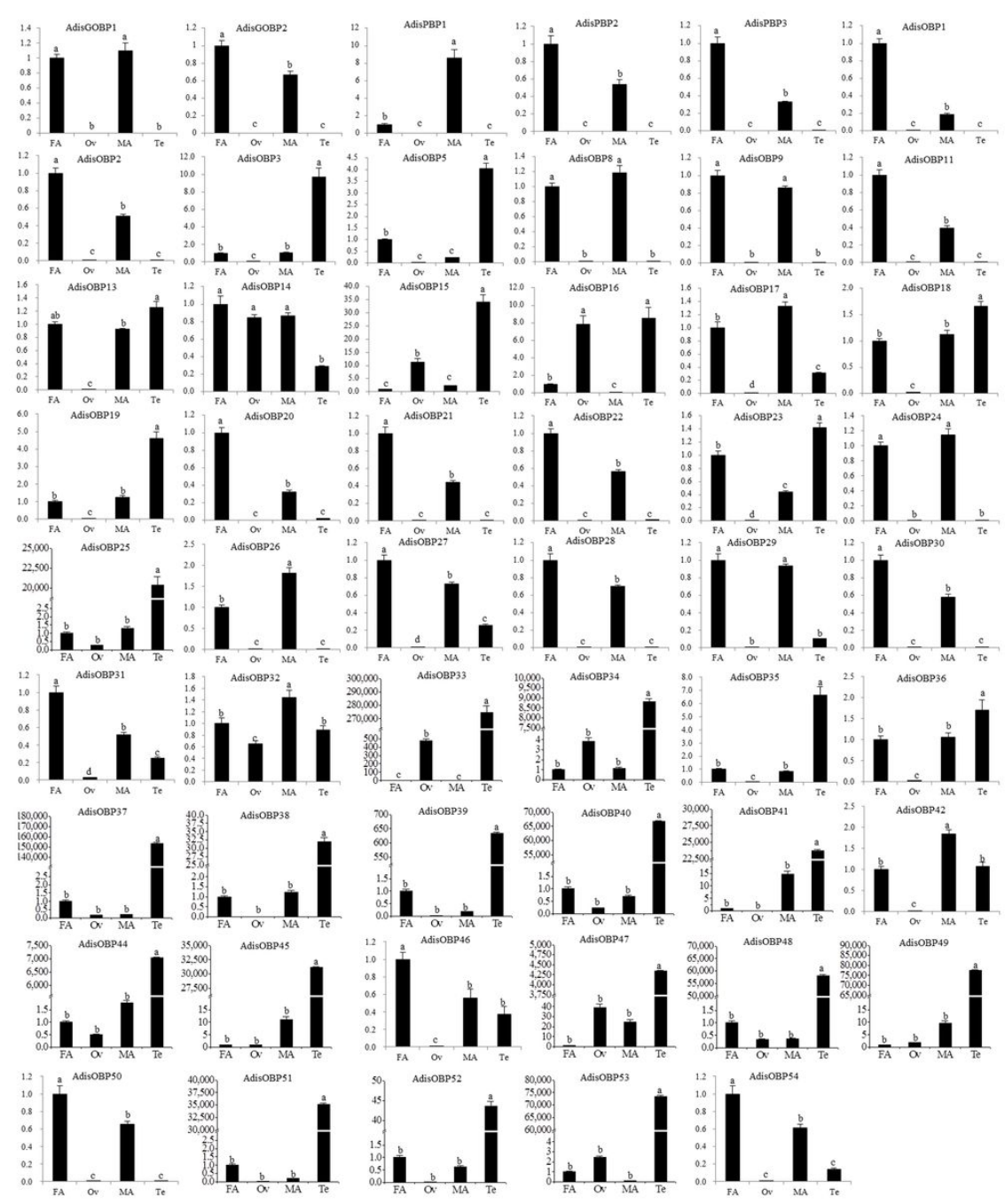

Figure 6

Expression profiles of the candidate OBPs in different tissues of A. dissimilis. FA: female antennae; MA: male antennae; Ov: ovaries; Te: testis. The standard errors are represented by the error bars; different lowercase letters $(a, b, c)$ above the bars denote significant differences at $p \otimes 0.05$.

\section{Supplementary Files}

This is a list of supplementary files associated with this preprint. Click to download.

- S2.txt

- S1.docx 